\title{
Number of Streptococcus mutans and Lactobacillus in saliva versus the status of cigarette smoking, considering duration of smoking and number of cigarettes smoked daily
}

\author{
Marta Nakonieczna-Rudnicka', Teresa Bachanek' \\ ${ }^{1}$ Department of Conservative Dentistry with Endodontics, Medical University of Lublin, Lublin, Poland \\ Nakonieczna-Rudnicka M, Bachanek T. Number of Streptococcus mutans and Lactobacillus in saliva versus the status of cigarette smoking, considering \\ duration of smoking and number of cigarettes smoked daily. Ann Agric Environ Med. 2017; 24(3): 396-400. doi: 10.5604/12321966.1228952
}

\begin{abstract}
Introduction and objective. A large number of colonies of Streptococcus mutans (SM) and Lactobacillus (LB) cariogenic bacteria in the saliva show a high risk of dental caries development. Cotinine is a biomarker of exposure to the tobacco smoke. The aim of the study was assessment of the number of Streptococcus mutans and Lactobacillus in the saliva of nonsmokers and smokers considering the duration of smoking and the number of cigarettes smoked daily. The number of SM and $L B$ was analysed in relation to the frequency of oral health check-ups.

Materials and method. The investigated group comprised 124 people aged 20-54.58 (46.8\%) reported cigarette smoking; $66(53.2 \%)$ reported they had never smoked cigarettes and had never attempted to smoke. Cotinine concentration in the saliva was assayed using the Cotinine test (Calbiotech), and the number of SM and $L B$ with the use of the CRT bacteria test (Ivoclar Vivadent, Liechtenstein). Statistical analysis was conducted using Chi ${ }^{2}$ and Mann-Whitney tests. Test values of $p<0.05$ were considered statistically significant.

Results. No essential correlation was stated between the number of SM and $L B$ and the status of smoking, the number of cigarettes smoked daily and duration of cigarette smoking. Smokers who reported having dental check-ups at least once a year significantly more frequently had a small number of LB stated in relation to people who had dental check-ups to control their oral health less frequently than once a year.

Conclusion. The number of SM and LB in saliva does not depend on the smoking status, the number of cigarettes smoked daily and duration of smoking.
\end{abstract}

\section{Key words}

Streptococcus mutans, Lactobacillus, cotinine, smoking

\section{INTRODUCTION}

Dental caries is connected with the presence of acidogenic and acidophilic bacteria in dental plaque, especially Streptococcus mutans $(S M)$ and Lactobacillus $(L B)$ which produce acids from sugars found in food. The action of acids on enamel hydroxyapatites causes demineralization which may initiate the cariogenic process. Saliva, which is the environment of the oral cavity, affects the demineralization and remineralization processes, dissolves and eliminates sugars, has buffering capacity and antibacterial properties $[1,2]$.

A high number of Streptococcus mutans and/or Lactobacillus in the saliva is one of the risk factors of the cariogenic process [3]. SM bacteria initiate caries of the enamel and the surface of a tooth root. In vitro studies revealed that with a $\mathrm{pH}$ value of 5.0 SM and $L B$ bacteria predominating, a further decrease of the $\mathrm{pH}$ value to 4.5 causes a further increase in their number, whereby $L B$ bacteria increase faster than $M S$ with $\mathrm{pH} \leq 4.6[4]$.

The biomarker of exposure to tobacco smoke is cotinine nicotine metabolite in its half-life which is $16-20$ hours in the

Address for correspondence: Marta Nakonieczna-Rudnicka, Department of Conservative Dentistry with Endodontics, Medical University of Lublin, Lublin, Poland

E-mail: stomzach@wp.pl

Received: 21 February 2016; accepted: 27 October 2016; first published:December, 2016 saliva. Cotinine concentration may be assayed in the saliva, plasma or urine. Cotinine half-life in the saliva and plasma are similar. Analysis of cotinine concentration in the saliva enables objective evaluation of exposure to tobacco smoke and verification of the survey data. Cotinine concentration in the saliva is related to the number of cigarettes smoked. Cotinine concentration in both in non-stimulated and stimulated saliva obtains similar values $[5,6,7,8,9,10]$.

Saliva present in the oral cavity is a mixture of secretions from the minor and major salivary glands and is called whole saliva. Non-invasiveness and the ease of saliva collection makes it a good diagnostic material. Saliva composition and salivary flow rate depend on the method of collection. The secretion of stimulated saliva is due to chewing, e.g. a paraffin cube, and causes an increased rate of salivary, whereas non-stimulated saliva is secreted with no influence on extrinsic factors [11].

\section{OBJECTIVE}

The aim of the study was assessment of the number of Streptococcus mutans and Lactobacillus in the saliva of nonsmokers and smokers, considering the duration of smoking and the number of cigarettes smoked daily. The number of $S M$ and $L B$ was analysed in relation to the status of smoking and the frequency of oral health check-ups. 


\section{MATERIALS AND METHOD}

Study sample. The investigated group comprised 124 people aged 20-54 who reported to the Chair and Department of Conservative Dentistry with Endodontics at the Medical University of Lublin. 58 (46.8\%) reported cigarette smoking; $66(53.2 \%)$ reported they had never smoked cigarettes and had never attempted to smoke. In the group of smokers, $53(90.4 \%)$ answered all the questions in the survey questionnaire, and 63 (95.4\%) in the group of non-smokers. From among 53 smokers, a duration of smoking of up to 10 years was stated by $29(54.7 \%)$ smokers and more than 10 years by $24(45.3 \%)$. The mean age of smokers was 31.8 , in non-smokers - 29.0. Women constituted $65.5 \%$ of those investigated, men $-34.5 \% .75 .0 \%$ of the investigated lived in a city and $25.0 \%$ in the country.

The exclusion criteria from participation in the study were: pregnancy, chronic and co-existing diseases, permanent medicine taking, nicotine replacement therapy, cigarette smoking in the past, antibiotic therapy and professional application of fluorine within 3 months prior to the study. The study was approved by the Bioethics Board of the Medical University in Lublin.

Salivary sample collection. Non-stimulated mixed saliva was collected into Salivette test tubes (Sarstedt, Germany) between $09.30-11.30,1.5$ - 2 hours after a meal during 10 minutes. Test tubes were placed in the ice container with the temperature of $4^{\circ} \mathrm{C}$ and centrifuged at the temperature of $4^{\circ} \mathrm{C}$ for $12 \mathrm{~min}$. at $3,000 \mathrm{r} / \mathrm{min}$. The obtained supernatant was stored at the temperature of $-75^{\circ} \mathrm{C}$ until assessment of the evaluated parameter.

Assessment of cotinine in salivary samples. Salivary concentration in non-stimulated mixed saliva was assessed with immunoenzyme method using Cotinine ELISA test (Calbiotech), according to manufacturer's instructions.

\begin{abstract}
Assessment of the number of o colonies of Streptococcus mutans (SM) and Lactobacillus (LB) cariogenic bacteria in the saliva. Assessment of the number of $S M$ and $L B$ colonies was performed with the use of CRT bacteria test (Ivoclar Vivadent, Liechtenstein), according to manufacturer's instructions. Mixed saliva stimulated by chewing a paraffin cube was collected between 09.30 - 11.30, 1.5 - 2 hours after a meal, during 5 minutes. Saliva was collected into a plastic disposable cup by the method of spitting. Directly after saliva collection, the bacteriological test was performed. After opening the vial and removing the agar medium, an $\mathrm{NaHCO}_{3}$ tablet was placed at the bottom of the vial, protective films were removed from 2 agar surfaces and they were thoroughly saturated with saliva using a disposable pipette. Agar medium was placed in a test vial which was closed, marked with the patient's number and date of material collection, and placed in a vertical position in an incubator (Cultura, Vivadent). It was incubated at the temperature of $37^{\circ} \mathrm{C}$ for 48 hours. After the appointed time, the vial was removed from the incubator and density of $S M$ and $L B$ bacterial colonies was compared with a standard pattern $\left(<10^{5}\right.$ $\mathrm{CFU} / \mathrm{ml}$ and $\geq 10^{5} \mathrm{CFU} / \mathrm{ml}$, low and high $\mathrm{CFU} / \mathrm{ml}$ ).
\end{abstract}

Statistical Analysis. The obtained results were submitted to statistical analysis with the use of $\mathrm{Chi}^{2}$ and Mann-Whitney tests. Test values of $\mathrm{p}<0.05$ were considered statistically significant.

\section{RESULTS}

Analysis of the cotinine concentration in the saliva revealed a consistency with the status of cigarette smoking declared by the investigated. In the group of non-smokers, the cotinine concentration was undetectable; in the group of smokers, the highest value of cotinine concentration was $924.5 \mathrm{ng} / \mathrm{ml}$ (Tab. 1).

Table 1. Analysis of cotinine concentration $(\mathrm{ng} / \mathrm{ml})$ in the investigated group

\begin{tabular}{lcccccc}
\hline \multirow{2}{*}{ Variables } & \multicolumn{6}{c}{ Descriptive parameters } \\
\cline { 2 - 7 } & $\mathrm{N}$ & Mean & Me & Min & Max & SD \\
\hline $\begin{array}{l}\text { Cotinine } \\
\text { Non-smokers }\end{array}$ & 63 & 0.0 & 0.0 & 0.0 & 0.0 & 0.0 \\
\hline Cotinine smokers & 53 & 340.8 & 322,0 & 8.7 & 924.5 & 230.1 \\
\hline Age & 116 & 30.7 & 25.5 & 20.0 & 54.0 & 10.3 \\
\hline
\end{tabular}

$\mathrm{N}$ - total number of patients

Me-median

$\mathrm{SD}$ - standard deviation

The mean age in the non-smoking group was 29.9 years, and in the smoking group - 31.8. No significant correlation was stated between the status of cigarette smoking and age of those Investigated ( $\mathrm{Z}=1.07, \mathrm{p}>0.05)$ (Tab. 2).

Table 2. Status of cigarette smoking in relations to age of the investigated

\begin{tabular}{lccccc}
\hline Status of smoking & $\begin{array}{c}\text { Mean age } \\
\text { (in years) }\end{array}$ & $\mathrm{N}$ & SD & Me & $\begin{array}{c}\mathrm{Z}=1.07 \\
(-) \\
\mathrm{p}>0.05\end{array}$ \\
\hline Never & 29.9 & 63 & 10.1 & 25.0 & \\
\hline Yes & 31.8 & 53 & 10.6 & 27.0 & \\
\hline Total & 30.7 & 116 & 10.3 & 25.5 &
\end{tabular}

(-) no differences $p>0.05$

Analysis of the number of cariogenic bacteria revealed that in $28.6 \%$ non-smokers the value of $S M \geq 10^{5} \mathrm{CFU} / \mathrm{ml}$ was stated, whereas in $71.4 \%$ the value of was $S M<.10^{5} \mathrm{CFU} / \mathrm{ml}$. In the group of smokers, the values were $39.6 \%$ and $60.4 \%$, respectively. The number of $L B$ colonies $\geq 10^{5} \mathrm{CFU} / \mathrm{ml}$ of the saliva were stated in $42.9 \%$ of non-smokers and $49.1 \%$ smokers, whereas the value of $L B<10^{5} \mathrm{CFU} / \mathrm{ml}$ of the saliva of the investigated were $57.1 \%$ and $50.9 \%$, respectively. No essential correlation was stated between the number of $S M$ $\left(\chi^{2}=1.58 ; \mathrm{p}>0.05\right)$ and $L B\left(\chi^{2}=0.45 ; \mathrm{p}>0.05\right)$ and the status of smoking. However, a tendency of a higher number of $S M$ bacterial colonies was observed in smokers (Tab. 3).

Analysis of the number of cariogenic bacterial colonies in relation to the number of cigarettes smoked daily - less than 20 cigarettes and 20 cigarettes and more - revealed, that the value $S M \geq 10^{5} \mathrm{CFU} / \mathrm{ml}$ of the saliva occurred in $38.9 \%$ people smoking less than 20 cigarettes daily, and in $35.7 \%$ smoking 20 cigarettes and more daily. The value of $S M<10^{5} \mathrm{CFU} / \mathrm{ml}$ was stated in $61.7 \%$ and $64.3 \%$, respectively. No significant correlation was stated between the number of $S M$ and the number of cigarettes smoked daily $\left(\chi^{2}=0.04 ; \mathrm{p}>0.05\right)$. Assessment of the number of $L B$ bacterial colonies revealed that the value of $L B \geq 10^{5} \mathrm{CFU} / \mathrm{ml}$ of the saliva occurred in $47.2 \%$ who smoked less than 20 cigarettes and $57.2 \%$ who smoked 20 cigarettes daily. The $L B<.10^{5} \mathrm{CFU} / \mathrm{ml}$ value was stated in $52.8 \%$ and $42.9 \%$, respectively. No essential 
Table 3. Number of Streptococcus mutans and Lactobacillus bacteria (CFU/ml of saliva) in the investigated group

\begin{tabular}{|c|c|c|c|c|c|c|c|}
\hline \multirow{2}{*}{ SM Bacteria } & \multicolumn{2}{|c|}{ Non-smoker } & \multicolumn{2}{|c|}{ Smoker } & \multicolumn{2}{|c|}{ Total } & \multirow{5}{*}{$\begin{array}{c}x^{2}= \\
1.58(-) \\
p>0.05\end{array}$} \\
\hline & $\mathrm{N}$ & $\%$ & $\mathrm{~N}$ & $\%$ & $\mathrm{~N}$ & $\%$ & \\
\hline High & 18 & 28.6 & 21 & 39.6 & 39 & 33.6 & \\
\hline Low & 45 & 71.4 & 32 & 60.4 & 77 & 66.4 & \\
\hline Total & 63 & 100.0 & 53 & 100.0 & 116 & 100.0 & \\
\hline \multicolumn{7}{|l|}{$L B$ bacteria } & \multirow{4}{*}{$\begin{array}{c}x^{2}= \\
0.45(-) \\
p>0.05\end{array}$} \\
\hline High & 27 & 42.9 & 26 & 49.1 & 53 & 45.7 & \\
\hline Low & 36 & 57.1 & 27 & 50.9 & 63 & 54.3 & \\
\hline Total & 63 & 100.0 & 53 & 100.0 & 116 & 100.0 & \\
\hline
\end{tabular}

$S M$ number $=$ high $\left(\geq 10^{5} \mathrm{CFU} / \mathrm{ml}\right) ; \angle B$ number $=$ high $\left(\geq 10^{5} \mathrm{CFU} / \mathrm{ml}\right)$

$S M$ number $=\operatorname{low}\left(<10^{5} \mathrm{CFU} / \mathrm{ml}\right) ; \angle B$ number $=\operatorname{low}\left(<10^{5} \mathrm{CFU} / \mathrm{ml}\right)$.

$\%$ - percentage of the investigated

correlation was stated between $L B$ number and the number of cigarettes smoked daily $\left(\chi^{2}=0.40 ; \mathrm{p}>0.05\right)$ (Tab. 4$)$.

Table 4. Number of $S M$ and $L B C F U$ / $\mathrm{ml}$ of saliva in relation to smoked cigarettes

\begin{tabular}{|c|c|c|c|c|c|c|c|}
\hline \multirow{3}{*}{$S M$ bacteria } & \multicolumn{6}{|c|}{ Number of smoked cigarettes/day } & \multirow{3}{*}{$\begin{array}{c}\mathrm{X}^{2}=0.04 \\
(-) \\
\mathrm{p}>0.05\end{array}$} \\
\hline & \multicolumn{2}{|c|}{$\begin{array}{l}\text { less than } 20 \\
\text { cigarettes }\end{array}$} & \multicolumn{2}{|c|}{$\begin{array}{l}20 \text { cigarettes and } \\
\text { more }\end{array}$} & \multicolumn{2}{|c|}{ total } & \\
\hline & $\mathrm{N}$ & $\%$ & $\mathrm{~N}$ & $\%$ & $\mathrm{~N}$ & $\%$ & \\
\hline High & 14 & 38.9 & 5 & 35.7 & 19 & 38.0 & \\
\hline Low & 22 & 61.1 & 9 & 64.3 & 31 & 62.0 & \\
\hline Total & 36 & & 14 & & 50 & 100.0 & \\
\hline \multicolumn{7}{|l|}{$\angle B$ bacteria } & \multirow{4}{*}{$\begin{array}{c}x^{2}=0.40 \\
(-) \\
p>0.05\end{array}$} \\
\hline High & 17 & 47.2 & 8 & 57.1 & 25 & 50.0 & \\
\hline Low & 19 & 52.8 & 6 & 42.9 & 25 & 50.0 & \\
\hline Total & 36 & & 14 & & 50 & 100.0 & \\
\hline
\end{tabular}

A high number of SM colonies was stated in $34.5 \%$ who smoked for up to 10 years and $40.9 \%$ who smoked for more than 10 years; there was a small number of $S M$, respectively, in $65.5 \%$ and $59.1 \%$ of the smokers. A high number of $L B$ was stated in $41.4 \%$ who had smoked for up to 10 years, and $59.1 \%$ of the investigated who had smoked for more than 10 years; there was a small number of $L B$, respectively, in $58.5 \%$ and $40.9 \%$ of the smokers. No essential correlation was stated between the number of $S M\left(\chi^{2}=0.22 ; \mathrm{p}>0.05\right)$ and $L B\left(\chi^{2}=1.57 ; \mathrm{p}>0.05\right)$ bacterial colonies and the duration of cigarette smoking, i.e. up to 10 years and more than 10 years (Tab. 5). In the group of smokers, a large number of SM was stated in $36.4 \%$ of the investigated who reported for dental check-ups.

A dental surgeon checked the state of oral health every 6 months, in $18.2 \%$ of people reporting once a year and in $45.4 \%$ reporting less than once a year. The $L B$ number was $23.1 \%$, $26.9 \%$ and $50.0 \%$, respectively. A low $S M$ number was stated, respectively, in $47.2 \%, 27.8 \%$ and $25.0 \%$, whereas there was a low $L B$ number in $59.4 \%, 21.8 \%$ and $18.7 \%$, respectively. Analysis of the $S M$ number in relation to the frequency of oral health check-ups did not reveal essential correlations between the assessed parameters $\left(\chi^{2}=2.6 ; \mathrm{p}>0.05\right)$. Smokers who reported having oral health check-ups every 6 months or once a year significantly more frequently had a small number of $L B$, compared to those who reported having oral health check-ups less than once a year $\left(\chi^{2}=8.8\right.$; $\left.p<0.05\right)$. In the group of non-smokers, a large number of $S M$ was stated in $50.0 \%$ of those who reported to a dental surgeon every 6
Table 5. Number of $S M$ and $\angle B C F U$ / $\mathrm{ml}$ of saliva in relation to duration of smoking

\begin{tabular}{|c|c|c|c|c|c|c|c|}
\hline \multirow{3}{*}{$S M$ bacteria } & \multicolumn{6}{|c|}{ Duration of smoking (years) } & \multirow{3}{*}{$\begin{array}{c}X^{2}=0.22 \\
(-)\end{array}$} \\
\hline & \multicolumn{2}{|c|}{ Up to10 } & \multicolumn{2}{|c|}{ More than 10} & \multirow{2}{*}{$\frac{\text { total }}{\mathrm{N}}$} & \multirow[t]{2}{*}{$\%$} & \\
\hline & $\mathrm{N}$ & $\%$ & $\mathrm{~N}$ & $\%$ & & & \\
\hline High & 10 & 34.5 & 9 & 40.9 & 19 & 37.3 & $p>0.05$ \\
\hline Low & 19 & 65.5 & 13 & 59.1 & 32 & 62.7 & \\
\hline Total & 29 & & 22 & & 51 & 100.0 & \\
\hline \multicolumn{7}{|l|}{$\angle B$ bacteria } & \multirow{4}{*}{$\begin{array}{c}X^{2}=1.57 \\
(-) \\
p>0.05\end{array}$} \\
\hline High & 12 & 41.4 & 13 & 59.0 & 25 & 49.0 & \\
\hline Low & 17 & 58.6 & 9 & 40.9 & 26 & 51.0 & \\
\hline Total & 29 & & 22 & & 51 & 100.0 & \\
\hline
\end{tabular}

months for a check-up on the state of their oral health; $38.9 \%$ reported once a year and $11.1 \%$ reported less than once a year. The $L B$ number was $53.6 \%, 32.1 \%$ and $14.3 \%$, respectively. A small $S M$ number was stated in $58.3 \%, 33.3 \%$ and $8.3 \%$, respectively, whereas $L B$ was in $57.9 \%, 36.8 \%$ and $5.3 \%$, respectively. Analysis of the number of $S M\left(\chi^{2}=0.39 ; \mathrm{p}>0.05\right)$ $\mathrm{d}$ and $L B\left(\chi^{2}=1.60 ; \mathrm{p}>0.05\right)$ cariogenic bacterial colonies in the group of non-smokers in relation to the check-up of oral health state did not reveal any significant correlations between the assessed parameters (Tab. 6).

Table 6. SM and $L B$ level (CFU/ml of saliva) in relations to oral check-ups

\begin{tabular}{|c|c|c|c|c|c|c|}
\hline \multirow{3}{*}{$\begin{array}{l}\text { Frequency of oral } \\
\text { check-ups } \\
\text { Smokers group }\end{array}$} & \multicolumn{5}{|c|}{ Number of SM colonies/ml of saliva } & \multirow{7}{*}{$\begin{array}{c}X^{2}= \\
2.64(-) \\
p>0.05\end{array}$} \\
\hline & \multicolumn{2}{|c|}{ High } & \multicolumn{2}{|c|}{ Low } & \multirow{2}{*}{ Total } & \\
\hline & $\mathrm{N}$ & $\%$ & $\mathrm{~N}$ & $\%$ & & \\
\hline Every 6 months & 8 & 36.4 & 17 & 47.2 & 25 & \\
\hline Once a year & 4 & 18.2 & 10 & 27.8 & 14 & \\
\hline Less than once a year & 10 & 45.4 & 9 & 25.0 & 19 & \\
\hline Total & 22 & & 36 & & 58 & \\
\hline \multirow{3}{*}{$\begin{array}{l}\text { Frequency of oral } \\
\text { check-ups } \\
\text { Smokers group }\end{array}$} & \multicolumn{5}{|c|}{ Number of $L B$ colonies $/ \mathrm{ml}$ of saliva } & \multirow{7}{*}{$\begin{array}{c}x^{2}= \\
8.81\left(^{*}\right) \\
p<0.05\end{array}$} \\
\hline & \multicolumn{2}{|c|}{ High } & \multicolumn{2}{|c|}{ Low } & Tatal & \\
\hline & $\mathrm{N}$ & $\%$ & $\mathrm{~N}$ & $\%$ & Totai & \\
\hline Every 6 months & 6 & 23.1 & 19 & 59.4 & 25 & \\
\hline Once a year & 7 & 26.9 & 7 & 21.9 & 14 & \\
\hline Less than once a year & 13 & 50.0 & 6 & 18.7 & 19 & \\
\hline Total & 26 & & 32 & & 58 & \\
\hline \multirow{3}{*}{$\begin{array}{l}\text { Frequency of oral } \\
\text { check-ups } \\
\text { Non-smokers group }\end{array}$} & \multicolumn{5}{|c|}{ Number of $S M$ colonies $/ \mathrm{ml}$ of saliva } & \\
\hline & \multicolumn{2}{|c|}{ High } & \multicolumn{2}{|c|}{ Low } & Total & \\
\hline & $\mathrm{N}$ & $\%$ & $\mathrm{~N}$ & $\%$ & & $X^{2}=$ \\
\hline Every 6 months & 9 & 50.0 & 28 & 58.3 & 37 & $0.39(-)$ \\
\hline Once a year & 7 & 38.9 & 16 & 33.3 & 23 & $p>0.05$ \\
\hline Less than once a year & 2 & 11.1 & 4 & 8.3 & 6 & \\
\hline Total & 18 & & 48 & & 66 & \\
\hline \multirow{3}{*}{$\begin{array}{l}\text { Frequency of oral } \\
\text { check-ups } \\
\text { Non-smokers group }\end{array}$} & \multicolumn{5}{|c|}{ Number of $L B$ colonies $/ \mathrm{ml}$ of saliva } & \multirow{6}{*}{$\begin{array}{c}x^{2}= \\
1.60(-) \\
p>0.05\end{array}$} \\
\hline & \multicolumn{2}{|c|}{ High } & \multicolumn{2}{|c|}{ Low } & Total & \\
\hline & $\mathrm{N}$ & $\%$ & $\mathrm{~N}$ & $\%$ & Iotal & \\
\hline Every 6 months & 15 & 53.6 & 22 & 57.9 & 37 & \\
\hline Once a year & 9 & 32.1 & 14 & 36.8 & 23 & \\
\hline Less than once a year & 4 & 14.3 & 2 & 5.3 & 6 & \\
\hline Total & 28 & & 38 & & 66 & \\
\hline
\end{tabular}

$\left.{ }^{*}\right)$ difference on the level of $\mathrm{p}<0.05$ 


\section{DISCUSSION}

Salivary tests enable assessment of the number of $S M$ and $L B$ cariogenic bacteria in the saliva of selected patients with a high level of bacteria, and monitoring the effectiveness of therapies resulting in a decrease in the number of bacteria. The tests are helpful in the evaluation of patients' dietary habits because the $L B$ number positively correlates with the consumption of carbohydrates in the diet. In the future, prognostication of dental caries in patients based only on bacterial salivary tests is not to be recommended because dental caries is a multifactorial disease. The cariogenic process, among others, is influenced by saliva secretion and saliva composition, general state of health, exposure to fluorine, frequency of sugars consumption, and sociodemographic status $[12,13]$.

Nishikawara et al. [14] demonstrated essential correlation between $L B$ level, the number of carious teeth and the number of proximal surface caries.

$S M$ bacteria are a significant marker of the onset of primary and secondary dental caries while $L B$ bacteria have a low ability to adhere to the enamel surface; however, they probably accumulate in marginal fissures of the filling. Therefore, there is a greater possibility for the development of secondary dental caries in people having numerous fillings [15].

Akpata et al. [16] revealed essential differences in the number of $S M$ and $L B$ bacteria in a group of people having at least 8 teeth with caries and in the group with no caries. They stated the number of $S M$ at $>10^{5} \mathrm{CFU} / \mathrm{ml}$ in $56.1 \%$ people with caries and in $11.1 \%$ people with no caries, for $L B>10^{5} \mathrm{CFU} / \mathrm{ml}$ the values were, respectively, $71.4 \%$ and $19.4 \%$.

Studies conducted in Turkey by Karaoğlanoğlu et al. [17] in a group of 133 people aged 20-50 demonstrated the number of $S M \geq 10^{5} \mathrm{CFU} / \mathrm{mL}$ colonies in $69 \%$ of women and $65 \%$ of men, whereas for $L B$ these values were $95 \%$ and $90 \%$, respectively. The authors did not state any essential differences between DMFS (mean of decayed, missing, filled permanent surfaces) index and the $L B$ or SM levels. The study was conducted with the use of CRT bacteria test (Ivoclar Vivadent AG, Schaan, Liechtenstein).

The results of the presented study revealed large number of SM colonies in $28.6 \%$ of non-smokers and $39.6 \%$ of smokers; for $L B$ the values were $42.9 \%$ and $49.1 \%$, respectively. No data was found in the available literature concerning correlations between the number of $S M$ and $L B$, and the number of cigarettes smoked daily and smoking duration.

Studies conducted by Huang et al. [18] revealed that nicotine increases the formation of biofilm by the action of $S M$ bacteria, and its metabolic activity on teeth surfaces which suggests the possibility of increased risk of dental caries in smokers.

Carrying out proper hygiene procedures in the oral cavity is an essential factor of caries prophylaxis and periodontal diseases.

Analysis of oral hygiene behaviours shows that smokers, in comparison to non-smokers, less frequently report for oral check-ups every 6 months, less frequently brush their teeth at least twice a day, less frequently use dental floss to maintain hygiene of interdental spaces as well as proximal surfaces, and they more frequently brush their teeth improperly $[19,20]$.

Dental caries is an infectious disease. Studies reveal that mothers who have a poor state of dentition have a high level of SM in the saliva, and may transfer bacteria to their babies, e.g. by licking the pacifier [21]. Awareness of dental caries risk factors may result in the modification of pro health habits.

The results of the presented study demonstrate that smokers who reported for oral health check-ups every 6 months or once a year, essentially more frequently had a low number of $L B$ in the saliva. It can be presumed that during oral health check-ups, the smokers obtained dietary instructions from their dental surgeon and information on proper oral hygiene procedures.

\section{CONCLUSIONS}

The number of $S M$ and $L B$ in the saliva is not related to the smoking status, number of cigarettes smoked daily and duration of smoking. A low number of $L B$ colonies was more frequently stated in the group of smokers who reported for dental check-ups at least once a year.

\section{Acknowledgement}

The study was funded by government funds for science in 2010-2014, Research Project. Grant NN 403111739.

\section{REFERENCES}

1. Marsh PH. Dental plaque as a biofilm and a microbial community implications for health and disease. BMC Oral Health. 2006; 6(Suppl 1): S14

2. Llena-Puy C. The rôle of saliva in maintaining oral health and as an aid to diagnosis. Med Oral Patol Oral Cir Bucal 2006;11: E449-55.

3. Dziedzic A, Kubina R, Wojtyczka RD, Kabała-Dzik A, Tanasiewicz M, Morawiec T. The antibacterial effect of ethanol extract of polish propolis on mutans streptococci and lactobacilli isolated from saliva. Evid Based Complement Alternat Med. 2013;2013:681891. doi: 10.1155/2013/681891.

4. Takahashi N, Nyvad B. The Role of Bacteria in the Caries Process: Ecological Perspectives. J Dent Res. 2011; 90(3): 294-303.

5. Benowitz NL, Jacob P III, Ahijevych K, Jarvis MJ, Hall S, LeHouezec J et al. Biochemical verification of tobacco use and cessation. Nicotine Tob Res. 2002; 4: 149-159.

6. Fu M, Fernandez E, Martinez-Sanchez JM, Pascual JA, Schiaffino A, Aguado A et al. Salivary cotinine concentrations in smokers in Barcelona, Spain: a cross-sectional study. BMC Public Health. 2009; 320 http://www.biomedcentral. com/1471-2458/9/320

7. Etter JF, Vu Duc T, Perneger TV. Saliva cotinine levels in smokers and nonsmokers. Am J Epidemiol. 2000; 151: 251-258.

8. Zevin S, Jacob P III, Geppetti P, Benowitz NL. Clinical pharmacology of oral cotinine. Drug Alcohol Depen. 2000; 60: 13-18.

9. Bachanek T, Nakonieczna-Rudnicka M, Piekarczyk W. Stimulated and non-stimulated saliva as biological material in the assessment of cotinine concentration. Prz. Lek. 2015; 72: 493-495.

10. Kamer B, Pasowska R, Grys W, Socha-Banasiak A, Kamer-Bartosińska A, Matczak-Rynkowska A et al. Pre- and postnatal exposure of children to tobacco smoke during the first four years of life - observations of the authors. Ann Agric Environ Med. 2104; 21(4): 753-759. doi: 10.5604/12321966.1129928

11. Lee YH, Wong DT. Saliva: An emerging biofluid for early detection of diseases. Am J Dent. 2009, 8; 22(4): 241-248.

12. Selwitz RH, Ismail AI, Pitts NB. Dental caries. Lancet. 2007; 369:51-59.

13. Fontana M, Zero DT. Assessing patients' caries risk. JADA. 2006;137(9):1231-1239.

14. Nishikawara F, Katsumura S, Ando A, Tamaki Y, Nakamura Y, Sato $\mathrm{K}$ et al. Correlstion in cariogenic bacteria and dental caries in adult. J Oral Sci. 2006; 48: 245-251.

15. Ito A, Hayashi M, Hamasaki T, Ebisu S. How Regular Visits and Preventive Programs Affect Onset of Adult Caries. J Dent Res. 2012; 91, suppl1: 52S-58S.

16. Akpata ES, Al-Attar A, Sharma PN. Factors associated with severe caries among adults in Kuwait. Med Princ Pract. 2009; 18: 93-99. 
17. Karaoğlanoğlu S, Akgül N, Akgül HM. The association between the DMFS index and levels of salivary Streptococcus mutans and lactobacill of subjects living in Erzurum, Turkey. J Dent Sci. 2010;5(2):70-74.

18. Huang R, Li M, Gregory R.L.Nicotine promotes Streptococcus mutans extracellular polysaccharide synthesis, cell aggregation and overall lactate dehydrogenase activity. Arch Oral Biol. 60, 2015, 1083-1090.

19. Bachanek T, Nakonieczna-Rudnicka M, Piekarczyk W. Stężenie kotyniny w ślinie w relacji do przeprowadzania zabiegów higienicznych w jamie ustnej. Prz Lek. 2014; 71 (11): 616-619.
20. Nakonieczna-Rudnicka M, Bachanek T, Kobyłecka E. Częstość badań stanu zdrowia jamy ustnej w grupie osób w wieku 20-54 lata z uwzględnieniem statusu palenia papierosów. Prz Lek. 2015; 72 (10): 548-552.

21. Kloetzel MK. Referrals for Dental Care During Pregnancy. J Midwifery Womens Health. 2011; 56(2): 110-117. 